\title{
The First American Public Utility
}

IN I 7 I , Englishmen interested in news from North America were entertained by a representation of the efficiency displayed by $\mathrm{Ca}$ nadian beavers in dam building, engraved in the border of a "New and Exact Map of the Dominions of the King of Great Britain" on this continent. The map is in an atlas of Herman Moll, a prominent British cartographer of the early eighteenth century. The atlas is a recent acquisition of the Society. This particular map is in great demand by public utility companies, as the first historical reference to the production of water power in America, and copies of it, when they can be found, bring from two to three hundred dollars.

The legend under the illustration states that "ye Beavers of Canada, to stop the course of a Rivulet, in order to make a great Lake, about wch they build their habitations, fell large Trees with their Teeth, in such a manner as to make them come Cross ye Rivulet, to lay ye foundation of ye Dam; they make Mortar, and finish ye whole with great order and wonderfull Dexterity. According to ye French Accounts."

The engraver has elaborated on the methods of the beavers with a great deal of imagination. The picture shows an army of overgrown, leonine beasts, in systematic competition with Niagara, indicated more or less accurately, in the background. One is busy felling a tree, and a second crouches beside him with a cynical expression, ready for business again after he has made sure that his partner is doing a workmanlike job. Others are gnawing fallen branches into short lengths, carrying armfuls of these short pieces, or dragging loads of mud on their tails. A neat dwelling house stands on the shores of the beaver-made lake, much like an Esquimo's igloo, with a door to the landward, and another leading into the water, as further described by the French travellers.

In the day when the map was made, the British colonists were building up permanent settlements along the Atlantic coast, but the interior of the country was known chiefly to wandering French trappers and missionaries, and their remarkable tales were the principal source of information about that little known region, for curious Europeans. Other maps in the atlas show some knowledge of the Spanish part of the country in the south. The northwestern section of the continent, however, is shown without a boundary, and designated as "parts unknown." 


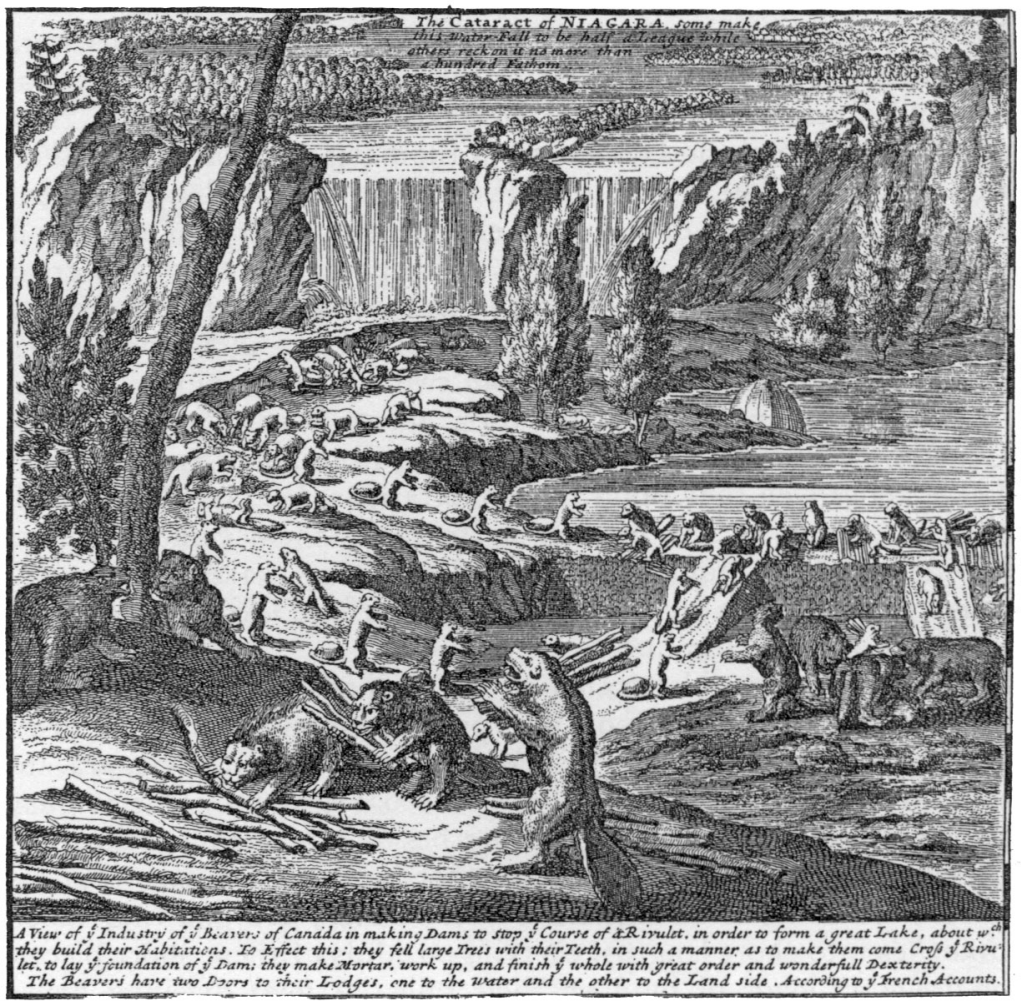

\section{Division of Labor among Canadian Beavers}

This first recorded reference to the artificial production of water power in America, taken from an eighteenth-century atlas, is much sought for by Public Utility Companies. 
The science of map-making had advanced greatly, even in the last century. As accuracy increased, the elaborate ornamentation of maps waned. By the time of Herman Moll, the pictures and scroll-work had become incidental, and less fanciful than supposedly instructive. Instead of the sea monsters, ships, and wild beasts which earlier map makers scattered about to fill in areas about which nothing was known, Moll and his contemporaries confined themselves to a picture or two in the margin, illustrating the industries of the country, the types of inhabitants, the principal cities, or "whatever was most remarkable."

After 1700 , the error in the measurement of the earth, adopted by Ptolemy from the astronomer Posidonius, which had been the basis of the distortion of mediaeval maps, was abandoned. And although Moll's maps are less decorative than those of his predecessors, there is some truth in the claim he makes on his title page to have "corrected the Errors of antient Geographers."

\section{JIn fllemoriam}

THE Society suffered a severe loss in the death of Mr. Howard Elliott, for years an outstanding figure in the railroad world. His own field was in the middle west, where he rose from a position as rodman with the Burlington system, while he was still a student at Harvard, to the presidency of the Northern Pacific Railway, in the space of twenty-three years. However, he was of New England stock, educated at the Lawrence Scientific School of Harvard University, and a descendant of John Elliott who settled Boston in I63I, and it was not unfitting that he should have been the one called upon to put the New York, New Haven and Hartford Railroad back on its feet at a time when the road was, both physically and financially, in a condition that almost bordered on wreck.

Indeed, an hour after the train bringing the new president east had passed through North Haven, Connecticut, there occurred in that town one of the worst wrecks in railroad history. His handling of the emergency showed the ability, tact and straightforwardness that was to rehabilitate the road, and gain for it the confidence both of the New England public and the press.

Immediately he reversed the rule regarding publicity which had existed on the New Haven road from time immemorial. Newspaper men were admitted to Mr. Elliott's office, and he promised 